\title{
Influence of Catastrophe Risk on Insurance and Reinsurance Markets
}

\author{
Hana Bártová*
}

\begin{abstract}
:
Insurance and reinsurance markets are exposed to influence of unsystematic catastrophe risk, which is caused by adverse development in natural disasters. Deepening of influence is highlighted in relation to irregular and extreme impacts of catastrophes. Insurers face to coverage of random loss events with contribution of reinsurers through a transfer of specified part of non-life risk. Influence of catastrophe risk is assessed through analysis of annual and quarterly development in catastrophe losses, impacts of floods, amount of premium written and reinsurance premium with respect to relations among selected variables. Analysis is focused on specific conditions of the Czech insurance market in context of reinsurance market. The findings concern to negative development in increasing catastrophe and flood losses, which seems to be not in line with changes in premium written, respectively reinsurance premium, which remain at stable level during analysed period. Respecting unfavourable aspect of insufficient data, results emphasize inadequate level of reinsurance of significant catastrophe risk, respectively floods, within the Czech insurance market.
\end{abstract}

Key words: Insurance; Reinsurance; Catastrophe; Flood.

JEL classification: G22, C58.

\section{Introduction}

Insurance and reinsurance markets are integral parts of financial market. Both markets have very close relationship due to coverage of risks, which forms a connection between participants of insurance and reinsurance markets represented by insurance undertakings and reinsurance companies. Increased frequency of natural disasters in recent years has contributed to elevated levels of specific category of insured non-life risks, i.e. catastrophic risk, and as a consequence has highlighted the importance of optimal reinsurance strategy for insurance undertakings. However, significant part of catastrophes is caused by floods. The occurrence of irregular low-probability high-impact catastrophic events influences negatively insurance undertakings and reinsurance companies. Impacts of catastrophes can be described i.a. through development in premium written expressed by costs of insurance protection provided to insurers' clients and

\footnotetext{
Hana Bártová; University of Economics, Prague, Faculty of Finance and Accounting, Department of Banking and Insurance, W. Churchill Sq. 4, 13067 Prague, Czech Republic, <hana.bartova@vse.cz>.

The article is processed as an output of a research project Development Trends in Banking and Insurance in Conditions of Changing Financial Markets registered by the Internal Grant Agency under the registration number IGS F1/21/2016.
} 
reinsurance premium representing a part of premium written ceded to reinsurers in order to cover excessive impacts of catastrophic events. With respect to worsening development in extreme catastrophe and flood risks, a level of premium written, respectively reinsurance premium, should be suitable to cover all random catastrophe risks.

The main aim of the paper is to verify a presumption of changes in reinsurance premium as a part of premium written, which are not at comparable level of changes in catastrophe losses, respectively floods realized in conditions of the Czech market. We assume, that an irregular occurrence of catastrophes and particularly floods with extreme impacts through enormous losses do not cause such significant fluctuations in premium written, respectively reinsurance premium. Reactions and behaviour of selected variables will be therefore verified through correlation analysis with contribution of analysis focused on development in annual and quarterly time series of selected variables. Based on realized catastrophe losses within the sample period from 2008 to 2016, we will assess whether the increased incidence of catastrophe risk responds to a growth in the amount of premiums.

\section{Features of Catastrophe Risk Influence}

Insurance undertakings, such as representatives of insurance market, are exposed to influence of random loss events within non-life insurance. Reinsurance undertakings, such as representatives of reinsurance market, take risks from insurers for a purpose of risk ceding, which results in increased insurance capacity of insurance market.

Focusing on non-life risks, catastrophe risks belong to current issues with impacts on multinational level. Due to changing environment, catastrophic events are more frequent causing enormous losses accompanied by increasing number of victims and widespread damages. Worsening development is monitored by several stakeholders (e.g. Swiss Re, 2016). Impacts of catastrophe losses influence advanced and also emerging markets. However, further interest will be focused on central Europe, respectively on relatively small area of the Czech Republic, which is specific for high frequency of catastrophe risks, especially floods (ČAP, 2017). The area is typical for dense river network causing frequent floods with large impacts on property, infrastructure and lives (Čamrová and Jílková, 2004).

Impacts of losses covered by insurance undertakings are diversified by reinsurance. Coverage of risks is commonly transferred through retrocession to additional reinsurance. Ducháčková and Daňhel (2010) mention influence of interconnectedness between insurance and reinsurance companies resulting in disintegration of catastrophic risks covered by reinsurance. Respecting quantitative impacts of risk realization, insurance without appropriate coverage through 
reinsurance could hardly work. Taking into account random walk of catastrophe events, consequent losses are expected to increase premium written such as a tool of insurance protection used by risk-averse clients. Froot (2001) highlights losses, which are uncorrelated with financial aspect. In conditions of perfect markets, premium written should approximate expected losses. Respecting real economic conditions of imperfect markets, relation between catastrophe losses and premium written should be verified.

Dependencies between insurance and reinsurance in context of catastrophe risks are also pursued by Banks (2004). Several financial innovations are developed in order to transfer risks from subjects exposed to risks to insurers, respectively to reinsurers. Bases of financial innovations are often formed by insurance and reinsurance instruments. These instruments are able to cover consequences of natural catastrophes. Further, similar solutions can support an increase in capacity of insurance market. For reasons of simplicity, we will focus just on risk transferred from insurers to reinsurers through a share on premium written paid by insurers to reinsurers in the form of reinsurance premium.

Garven and Tennant (2003) analyse a relation between the demand for reinsurance and specify firm's decisions including firm's financial leverage, tax conditions, investments, ownership structure, geographic concentration etc. Several key drivers influence demand for protection against risks. Nevertheless, conclusions are closely related to reinsurance behaviour of property-liability insurance firms in conditions of US in 1980-1987. Our analysis will be focused on current development in influence of risks on insurance and reinsurance markets respecting main factors determining development trends.

Deteriorating development in catastrophic risk realization raises costs of insurers. A question of costs is mentioned by Cummins (2007), who add an aspect of regulation to overall impacts on effectiveness of reinsurance coverage through insurance market in US. Despite differences between American and Czech markets, the aspect of costs of reinsurance is relevant. This contributes to an implementation of solutions based on state participation through alternative risk transfer (Banks, 2004). Effective solution offered e.g. Czech government bonds, which were issued after catastrophic floods in 1997. Bonds belong to a group of instruments, which are able to compensate estimated catastrophe losses. However, realization of natural catastrophe depends on random fluctuation, which is connected with uncertainty (Pollner, 2012). Moreover, some of risks become systemic, which are hardly diminished and excluded from risk portfolio throughout standard methods including appropriate risk management based on complex modelling of risks (Faure and Hartlief, 2003). Otherwise the presence of enormous risks results in extended exclusion of particular risks from insurance protection, which weakens the role of commercial insurance. Insurance market has 
own limits (Berliner, 1985). Risk exclusion has also appeared in conditions of the Czech insurance market. Areas exposed to the highest frequency of floods have been classified as the most risky flood zones, which are practically uninsurable through standard insurance products. Such administrative solutions contribute to elimination of negative influences of catastrophe losses on insurance (reinsurance) markets, but it is unacceptable from the perspective of insurance buying public. Strengthening of catastrophe risk causes deeper relation between insurance and reinsurance markets with respect to mentioned aspects including a necessity of excessive catastrophe risk coverage. Signs of relations between both markets will be verified with contribution of relevant data analysis (Arlt and Arltová, 2009).

\section{Data and Methodology}

To evaluate main aim, selected variables will be analysed, i.e. premium written, reinsurance premium, catastrophe losses and losses of floods realized in the Czech Republic. Premium written is represented by prescribed premium, which follows from insurance contracts regarding non-life insurance within the Czech insurance market consisted of members of the Czech Insurance Association (i.e. 98\% of all premiums in the Czech Republic). Premium written is influenced by a level of net premium, which is derived from sum insured, number of contracts and insured events, applied interest rate and amount of losses. In other words, net premium is based on loss frequency and degree of loss. Net premium is a part of gross premium, which additionally includes risk premium, administrative costs and calculated profit of insurer. Premium written used in further analyses concerns to gross premium written of non-technical account for non-life insurance (hereinafter premium or premium written; $\breve{\mathrm{C} N B}, 2016$ ).

Certain part of risk exceeding a limit of insurer is ceded to reinsurer in the form of reinsurance premium. This premium is paid by insurers to cover additional risks in order to increase insurance capacity, to mitigate risks and to balance financial results of insurers. Within the meaning of this paper, reinsurance premium is a part of premium written. Reinsurance premium expresses gross premiums written ceded to reinsurers of non-technical account for non-life insurance (hereinafter re. premium or reinsurance premium; ČNB, 2016). Reinsurance premium is expressed as a difference between gross premium written and premium written adjusted by reinsurance, which are published by $\check{C}$ NB within non-technical account for non-life insurance ( $\breve{\mathrm{CNB}}, 2016)$.

Both premiums are calculated on annual and quarterly basis. Annual data has been taken directly from the database of ČNB. Quarterly data are published only as cumulative. Quarterly data in further analyses has been recalculated and expressed as quarterly increment in each quarter, which enables interquartile comparison. Variables of premium written and reinsurance premium are complemented by 
variables of catastrophe losses and losses of floods realized in the Czech Republic in selected time period. Data about development in catastrophes and floods is based on available statistics provided by the Czech association of insurers (ČAP, 2016). Total catastrophe losses concern losses made by natural disasters (ČAP, 2016). Losses caused by floods express a part of total catastrophe losses realized by specified non-life risk ( (̌AP, 2016). We consider only insurance events regarding insured losses. All data are listed in Appendix. Annual time series of selected variables are available in period from 2008 to 2016. Adjusted quarterly data are processed in the period from 4q2010 to 4q2016 with respect to limitations given by available information sources.

Besides impacts of unsystematic effects, development in selected variables is influenced by trend, seasonal and cyclical factors forming systematic components of time series. Trend factors reflect long-term changes in usual behaviour of time series, respectively general tendency of development in assessed course during long period. Seasonal factors explain periodic fluctuation in time series, which has systematic features. The fluctuation takes place through the year and repeats at regular intervals. Periodic fluctuation is caused by changes in seasons and also by human behaviour. Cyclical factors are referred to fluctuations around trend. Growth phases and decline phases are substituted. Particular cycles have irregular features and happen during periods longer than 1 year. Time series of selected variables face especially to seasonal factors, which have been observed within catastrophe and flood losses. Trend can be observed at least within continuous growth in premiums with exceptions regarding decreases caused by adverse economic conditions or human perception of risks, by change in human behaviour etc. General trend is expressed by growth in total amount of losses and premiums, which reflect ongoing increase in value of property, accumulation of wealth and last but not least climatic changes. Just dramatic changes in climate cause extreme natural catastrophes realized around the world ( $\mathrm{PwC}, 2015)$. Especially in developed economies, influence of catastrophes is much more significant in comparison with emerging countries (Swiss Re, 2015 and 2016). Increase in property contributes to higher nominal losses in case of risk realization. Nevertheless, catastrophes and floods are influenced by random development in risk realization. Influence of unsystematic component of time series is therefore undisputable, which is analysed in next chapters. Development in premiums and losses with respect to systematic and unsystematic components is an object of further analyses reflecting limited input data.

Features of input data have influenced applied methodology. Main method is represented by detailed comparative analysis of development in selected variables. Both premiums and losses realized in the Czech Republic have been assessed through analysis of development in annual and quarterly time series. To reach 
main aim, cooperation between insurance and reinsurance markets has been described through relevant factors and effects, which have impacts on relation between both markets influenced by catastrophic risks. Analyses have not considered losses caused by man-made disasters. Nevertheless, significant influence of seasonal factor has been found within quarterly time series. Data has been for this reason adjusted by seasonality through Census X-13 ARIMA seasonal adjustment. Further analysis has shown non-stationary development in both premiums on quarterly basis based on Dickey Fuller test of stationarity. Premium written and reinsurance premium have been then stationarized by taking the first differences. Catastrophe and flood losses have been recognized as stationary and used in further analyses as unchanged. Original values of selected variables used in further analyses are mentioned in Appendix.

Results of development in premiums and losses have been additionally derived from correlation analysis. The method has contributed to explanation of behaviour among variables through a determination of a level to which relation among variables can be considered as linear. Correlation coefficient measures the degree of linear association between two random variables. Values of correlation lie between -1 and +1 , which determine negative or positive linear relation between variables. Further, an absolute value indicates the strength of the linear association between values of random variables. Results in correlation analysis have been assessed regarding the strength of relations among catastrophes, floods, premium written and reinsurance premium. However, verification is significantly dependent on a range of available data and an influence of significant fluctuations within catastrophe and flood losses. These limitations have to be taken into account. Despite data limitations, correlation analysis has contributed to comparative analysis providing an overall view on behaviour among variables. Conclusions regarding related factors of development trends have been inferred through content analysis of available literature and other information resources. All conclusions of empirical analysis have been drawn from synthesis of assessed information.

\section{Analyses of Time Series}

The presumption of changes in reinsurance premium, which are not at comparable level of changes in catastrophe losses, respectively floods realized in conditions of the Czech market, is verified through analyses of annual and quarterly time series.

\subsection{Analysis of annual time series}

Analysis of annual time series is based on comparison of development in selected variables. Values of selected variables on annual basis (i.e. before any adjustments) are listed in Appendix 1. Calculation of both premiums related to non-life insurance is influenced by several factors including economic, social, technological, political and environmental changes ( $\mathrm{PwC}, 2015)$. Especially 
environmental changes are significantly connected with development in catastrophes and floods. In general premiums are derived from expected impacts of loss events, which are based on determination of probability. Calculation reflected in technical reserves is closely connected with risk mitigation and assessment of impacts on insurance operations (Cipra, 2006). Therefore, insurance undertakings and reinsurance companies develop and implement own sophisticated internal models, which reflect past and expected losses including premiums and reserves projections. Nevertheless, loss events occur in irregular intervals with negative impacts on prediction models, which fail especially after realization of excessive losses. Floods are affected by inappropriate preventive measures and human interventions in environment. Respecting a lack of relevant data, floods in conditions of the Czech Republic recognize signs of seasonality (see 4.2). Further, development in catastrophes is generated by random mechanism and connection with cyclical and trend factors is questionable. These factors do not work properly within development in insurance and reinsurance markets. In general, loss development can be moderate for many years followed by unexpected loss event with excessive impacts.

Influence of above mentioned factors is confirmed by development within selected variables. Total flood losses in the Czech Republic exceeded 7.7 bn CZK in 2010 and reached the level of 9.2 bn CZK in 2013. Ratio of floods on total catastrophic losses fluctuated annually in wide range from 5\% to 79\%. Total premium written amounted to 81.6 bn CZK in 2012 and 91.0 bn CZK in 2015. Reinsurance premium was recognized on the level of 22.7 bn CZK in 2009 and 26.9 bn CZK in 2015. Ratio of reinsurance premium on premium written has been maintained at stable level around $30 \%$ in long term.

Occurrence of risks affects the ratio of reinsurance premium on premium written very insignificantly. However, impacts can be delayed in time. Growth in premium written then includes a reaction of clients on realized risk in previous period. Reinsurance premium is a tool of following diversification of risks. Changes in reinsurance premium can be therefore postponed in relation to changes in premium written. Regarding stable level of the ratio, a reaction of insurers to high catastrophe losses is assessed as poor. To verify relations between premiums, especially reinsurance premium, and losses, Pearson's correlation has been calculated based on annual stationary data in period from 2008 to 2016 (see Tab. 1). Results of t-statistics have been added to Appendix 2.

Positive linear relationship based on results of correlation coefficients of selected variables has been analysed between premiums and losses. As expected, development in catastrophes and floods confirmed strong linear relationship. Correlation coefficients of reinsurance premium in relation to catastrophe and flood losses reached the level of 0.6271 , respectively 0.5163 . Moreover, in case of 
relation to catastrophe losses the correlation coefficient has been tested on $90 \%$ of significance level. At least to a certain extent, reinsurance premium responds to changes in catastrophe losses. This result confirms our presumption, which is verified. Nevertheless, increase in catastrophe losses is not fully covered by comparable increase in reinsurance premium. This can be effected i.a. by a certain level of risk, which is intentionally not included in coverage of insurers, respectively reinsurers. Estimated impacts on (re)insurers are irregular, rather rare and diversified during longer period by fluctuation reserves. Development in expected losses is further smoothened in internal risk models of insurers and reinsurers in order to eliminate exaggerated fluctuations in monitored variables, which could cause miscalculations with negative impact on appropriate assessment of risks.

Tab. 1 Pearson's correlation matrix in period 2008 - 2016

\begin{tabular}{|c|c|c|c|c|}
\hline & Catastrophe & Flood & D.Premium & D.Re.Premium \\
\hline Catastrophe & 1.0000 & & & \\
\hline Flood & $\begin{array}{l}0.9510 \\
(0.0001)\end{array}$ & 1.0000 & & \\
\hline D.Premium & $\begin{array}{l}0.2839 \\
(0.4956)\end{array}$ & $\begin{array}{l}0.4091 \\
(0.3142)\end{array}$ & 1.0000 & \\
\hline D.Re.Premium & $\begin{array}{l}0.6271 \\
(0.0961) \\
\end{array}$ & $\begin{array}{l}0.5163 \\
(0.1902) \\
\end{array}$ & $\begin{array}{l}0.3637 \\
(0.3758) \\
\end{array}$ & 1.0000 \\
\hline
\end{tabular}

Source: ČAP, 2017; ČNB, 2017; own calculations.

Note: $(*)$ p-value, two-tail test for significance; H0: correlation coefficient $=0$; H1: correlation coefficient $\neq 0 ; \mathrm{n}=8 ; \mathrm{df}=6 ; \mathrm{t}_{0.90}=1.943, \mathrm{t}_{0.95}=2.447, \mathrm{t}_{0.99}=3.707$.

Coefficients of premium written have reached lower levels of correlation and estimates were statistically insignificant. Results are affected i.a. by specific features of natural disasters and floods, which are realized randomly in irregular intervals with occasional extreme losses. Extreme losses are not expected to be repeated in a short time. Such unpredictable events do not usually cause higher interest in additional individual insurance protection by customers, which is connected with subjective perception of risks and a level of risk aversion. Moreover, the informative value of correlation analysis of yearly data is hindered by low number of observations and thus may produce distorted results in comparison with real development in selected variables.

According to results of correlation analysis we can assume, that insurers' reaction on catastrophic risks may seems to be not adequate. Increase in catastrophe losses is not fully covered by change in reinsurance premium, i.e. insurers do not increase reinsurance premium at comparable level in line with a growth in losses of catastrophes, respectively floods. This can be connected with above mentioned decomposition of risks in long-term within calculation of premiums. Additionally, 
insurers and reinsurers create reserves continuously considering legal requirements on solvency, which include coverage of unexpected and extreme losses. Random catastrophe losses with extremely high impacts and also income of premium are uniformed and balanced to mitigate irregular fluctuations, which would have negative influence on appropriate calculations of premiums and reserves. Therefore, coverage of especially unsystematic risks can seem as inappropriate based on relevant annual data. Conclusively, it is necessary to notice, that premiums are formed continuously and often is based on long-term (re)insurance contracts. In case of non-life risk realization, it is not possible to optimize concluded insurance protection immediately. Level of risk coverage is also dependent on consumers' risk behaviour. Moreover, availability of insurance protection can be negatively influenced by administrative measures, e.g. implementation of flood zones. Nevertheless, reinsurance premium should be increased much more significantly in relation to increasing and extreme impacts of catastrophes caused especially by floods. However, these conclusions cannot be accepted in general basis with respect to short time series and rather low levels of Pearson's correlation coefficients. For these reasons, an analysis of quarterly time series was additionally performed.

\subsection{Analysis of quarterly time series}

Values of selected variables within the assessed quarters are summarized in Appendix 3 (i.e. before adjustments for seasonality). For better understanding of influence of seasonal effects, data has been divided into individual quarters (see Tab. 2). Catastrophes and floods are visibly affected by seasonal effects.

\section{Tab. 2 Catastrophe loss, flood loss, reinsurance premium and premium written in individual quarters ( $m n$ CZK)}

\begin{tabular}{lllll}
\hline Quarter & Catastrophe & Flood & Premium & Re. Premium \\
\hline $1 \mathrm{q}$ & 191.2 & 32.5 & $23,077.0$ & $7,524.8$ \\
$2 \mathrm{q}$ & $1,849.5$ & $1,311.9$ & $21,636.2$ & $6,255.3$ \\
$3 \mathrm{q}$ & $1,357.6$ & 185.4 & $20,805.1$ & $6,087.5$ \\
$4 \mathrm{q}$ & 227.0 & 92.1 & $20,151.6$ & $6,024.4$ \\
\hline Total & $\mathbf{3 , 6 2 5 . 3}$ & $\mathbf{1 , 6 2 1 . 9}$ & $\mathbf{8 5 , 6 7 0 . 0}$ & $\mathbf{2 5 , 8 9 1 . 9}$ \\
\hline
\end{tabular}

Source: ČAP, 2017; ČNB, 2017; own calculations.

The most of catastrophes are realized in the second quarter (i.e. $51 \%$ of total catastrophe losses). Floods are also occurred mainly in the second quarter (i.e. $81 \%$ of total flood losses). This development is closely connected with weather reasons such as heavy rains, effects of droughts, hails, storms etc. influencing risk exposed area of the Czech Republic. In the first quarter catastrophes occur very 
rarely (i.e. only $5 \%$ of total catastrophe losses). Similar positive loss development is obvious in the fourth quarter. Floods are nearly not realized at the end of year (i.e. only $2 \%$ of total flood losses). According to these results, influence of seasonality is apparent due to climate conditions and features of the environment in the Czech Republic.

Development in premium written and reinsurance premium is much more balanced in comparison with the course of losses. Any significant changes through the quarters are analysed. The most of premium written is cumulated in the first quarter (i.e. $27 \%$ of total premium written). The lowest increment of premium written is recognized in the fourth quarter (i.e. $24 \%$ of total premium written). Average of premium written in individual quarters moves on the level of $25 \%$. Similar results concerns to reinsurance premium. The most of reinsurance premium is cumulated in the first quarter (i.e. $29 \%$ of total reinsurance premium). The lowest level of quarterly increment is reached in the fourth quarter (i.e. $23 \%$ of total reinsurance premium), which can be influenced i.a. by concluding new contracts especially at the beginning of the year, or tax purposes connected with the end of the year. Nevertheless, differences are indeed minor. Average of reinsurance premium in individual quarters equals to $25 \%$. Share of reinsurance premium on premium written moves on the level of $30 \%$ on average with any significant differences through the assessed period.

Analysis of quarterly reinsurance premium has not confirmed any significant fluctuations in selected time series (see Appendix 4). Reinsurance premium is cumulated in a balanced way in the course of particular year. The premium fluctuates in narrow interval from $5.5 \mathrm{mn}$ to $7.7 \mathrm{mn}$ CZK throughout the selected period. Premium written is also cumulated gradually during the whole year. Premium written fluctuates between $18.4 \mathrm{mn}$ and $21.1 \mathrm{mn}$ CZK. Development in quarterly premium written has also not showed any excessive changes in selected time series. However, fluctuation ban of premium written is more than twice wider in comparison with reinsurance premium, which is caused i.a. by higher absolute amount of premium written.

Comparing development in premiums and losses, premiums have not been influenced by significant seasonal changes. Premiums have not responded to excessive fluctuations within losses caused by catastrophic events, which is a result of above mentioned income of premium smoothened intentionally in longer time period by (re)insurers. Quarterly premiums do not reflect fluctuations in separate catastrophe events in any apparent way, which should be taken into account within internal risk modelling. Therefore, adjusted development in selected variables is necessary to further risk management. However, quarterly increase in catastrophe losses is not fully covered by quarterly increase in premiums. Differences in course of variables represented by unsystematic 
development in losses and stable share of reinsurance premium on premium written have contributed to a confirmation of necessary loss reinsurance and influence of catastrophe risk on insurance and reinsurance markets.

Relationship among selected variables on quarterly basis after adjustment for seasonality and based on stationary data has been expressed through correlation analysis (see Tab. 3).

Tab. 3 Pearson's correlation matrix in period 4q2010 - 4q2016

\begin{tabular}{lllll}
\hline & Catastrophe & Flood & D.Premium & D.Re.Premium \\
\hline Catastrophe & 1.0000 & & & \\
Flood & 0.9292 & 1.0000 & & \\
& $(0.0000)$ & -0.0878 & & \\
D.Premium & -0.0317 & $(0.6833)$ & 1.0000 & \\
\multirow{2}{*}{ D.Re.Premium } & $(0.8831)$ & 0.0709 & 0.6943 & 1.0000 \\
\hline
\end{tabular}

Source: ČAP, 2017; ČNB, 2017; own calculations.

Note: $(*)$ p-value, two-tail test for significance; H0: correlation coefficient $=0 ; \mathrm{H} 1$ : correlation coefficient $\neq 0 ; \mathrm{n}=24 ; \mathrm{df}=22 ; \mathrm{t}_{0.90}=1.717, \mathrm{t}_{0.95}=2.074, \mathrm{t}_{0.99}=2.819$.

Correlation coefficients of quarterly data have exhibited low relationship between both premiums and losses. Results of correlation between premium written and catastrophe, respectively flood losses have been calculated slightly below 0 (i.e. -0.0317 , respectively -0.0878). Reinsurance premium and losses has recognized positive relations. Correlation coefficients have reached considerably low levels of 0.0709 , respectively 0.0265 . However, results of correlation analysis are influenced by lower levels of statistical significance. Weak linear relationship has been confirmed reflecting insufficient input data. With respect to high p-values, we fail to reject hypothesis H0. Results have not verified direct reaction of reinsurance premium on development in losses. Detail of quarterly analysis is mentioned in Appendix 5.

Analysis of quarterly time series confirmed the assumption of seasonality and insufficient reinsurance of catastrophe losses represented by unchanging ratio of reinsurance premium on premium written with respect to excessive fluctuations within catastrophe and flood losses. Both premiums are developed comparably. Catastrophes fluctuate and occur especially in the second and in the third quarters. However, all findings of quarterly analysis are negatively influenced by short time series and unavailability of relevant data about unsystematic natural disasters and premiums. Disregarding insufficient data and low levels of statistical significance, coverage of catastrophe loss events could be improved through comparable changes in reinsurance premium considering irregular but still significant loss 
Bártová, H..: Influence of Catastrophe Risk on Insurance and Reinsurance Markets.

impacts on insurance and reinsurance markets represented by insurers and reinsurers.

\section{Results and Discussion}

Analysis of annual time series of selected variables highlighted unsystematic development in losses caused by natural catastrophes, respectively floods. Otherwise, course of premium written and reinsurance premium is relatively balanced without any significant changes in assessed period.

\section{Fig. 1 Annual development in catastrophe loss, flood loss, reinsurance} premium and premium written in 2008 - 2016 ( $m$ n CZK)

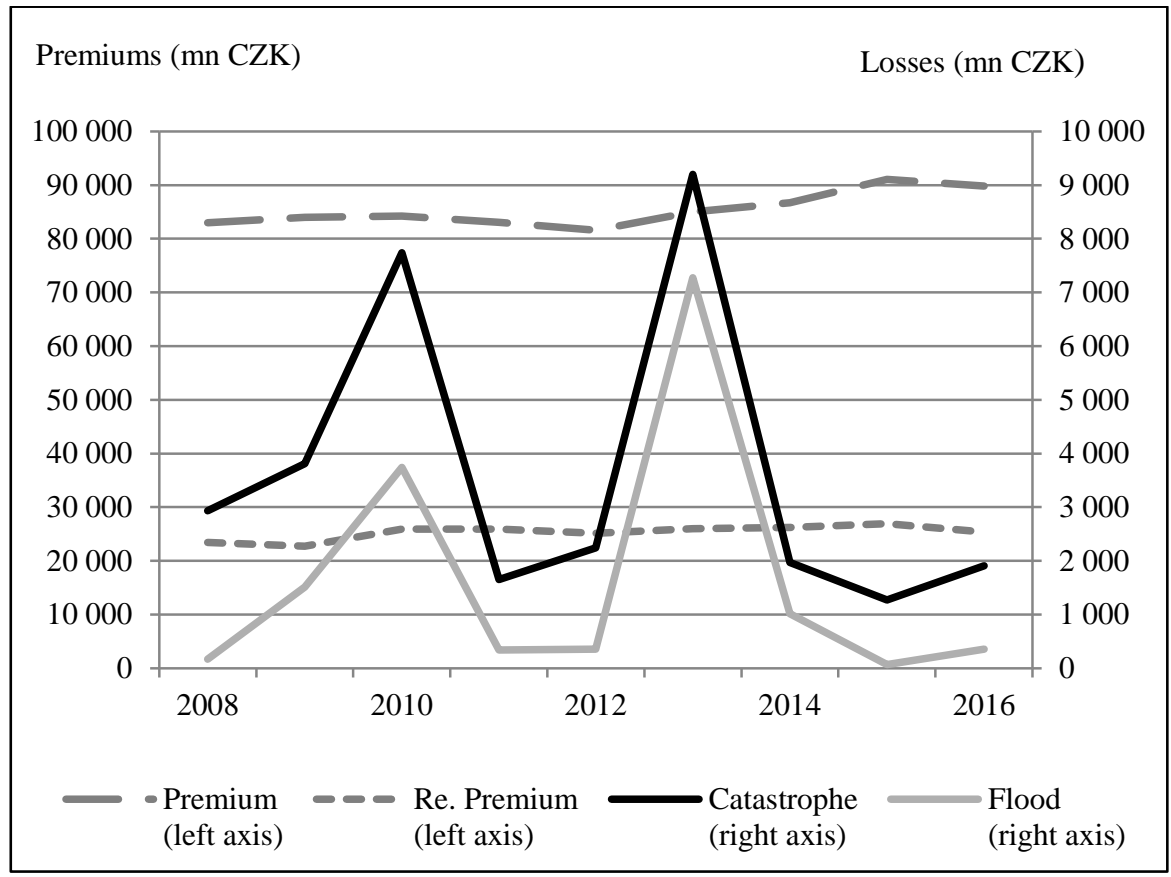

Source: ČAP, 2017; С̆NB, 2017.

Any significant reaction of premiums on negative loss development, especially in 2010 and 2013, is recorded. Premium written is determined by interest of insurers' clients in commercial insurance protection against loss impacts. Nevertheless, the level of reinsurance premium such as a part of risk transferred from insurers to reinsurers remains almost unchanged. Regarding unsystematic catastrophe losses, reinsurance of insurance undertakings seems inappropriate. Sensitivity of changes in premiums in relation to fluctuations in losses is too low. However, results in correlation analysis have confirmed relatively strong linear relationship between 
reinsurance premium and catastrophes, but changes in reinsurance premium have not responded to changes in losses at fully comparable level.

Irregular development in losses has recognized signs of seasonality, which was confirmed by analysis of quarterly time series. The most of catastrophes and floods occur in the second, respectively in the third quarters. Otherwise, development in premium written and reinsurance premium is stable at comparable levels in each of individual quarters. Premiums have not responded directly to higher losses. Moreover, ongoing increase in premiums is not in line with increase in excessive losses. Results in correlation analysis have confirmed positive relationship between reinsurance premium and losses, but levels of significance are too low. Insurance protection of insurers against extreme losses seems rather weak. This can be caused also by conscious decision of insurers. Specified part of risk can be intentionally accepted and not covered by reinsurance. Eventually, reserves to cover risks are created gradually in longer time period with any significant impacts on total amount of premiums in particular periods. Excessive losses are above that hardly identified. Predictive insurance models often fail. Insurers, who consider a part of uncovered risk, can achieve economies of scale due to risk taking and avoiding from expensive investments in complex risk management tools with uncertain effects.

\section{Fig. 2 Comparison of development in selected variables in individual quarters (mn CZK)}

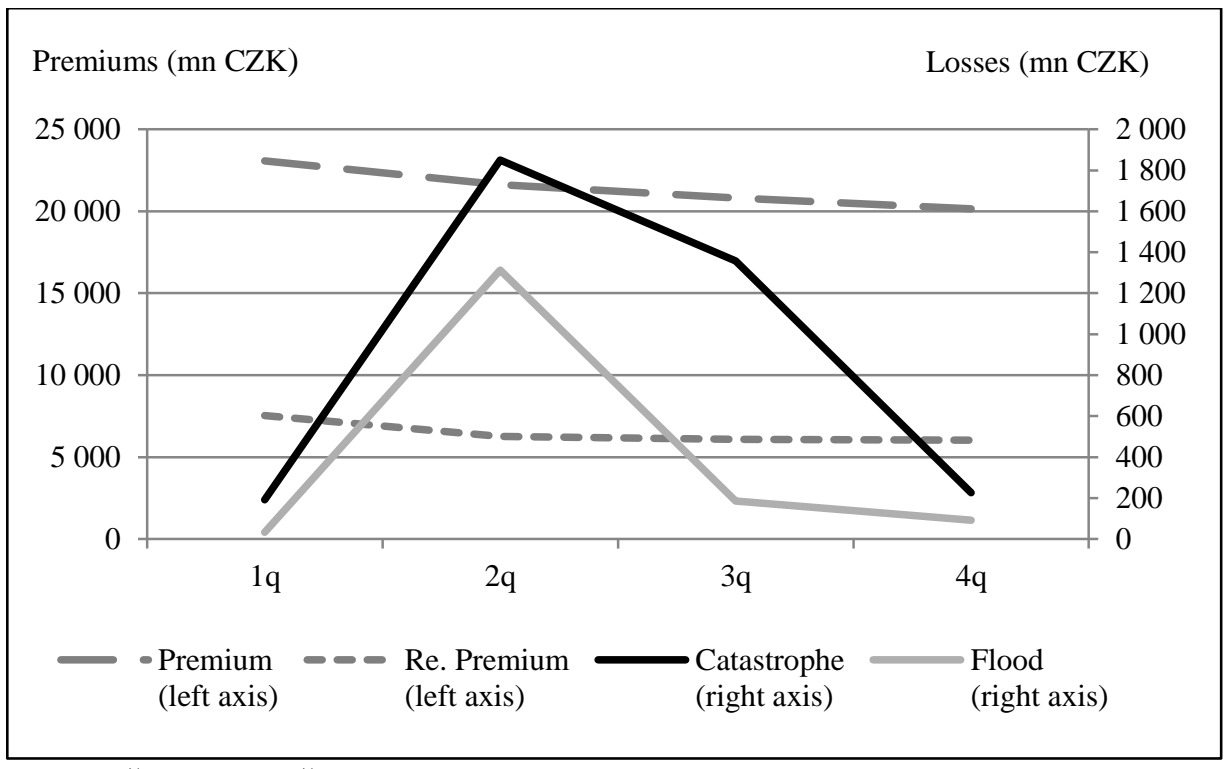

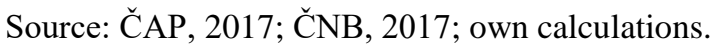


Both premiums develop in the same direction, but it is rather caused by continuous development than close relation to changes in impacts of loss events. This can result in insufficient level of reinsurance in periods with realization of extreme floods and other natural disasters. Nevertheless, this finding is based on aggregated data. Individual insurer can react differently and more sensitively.

Annual and quarterly time series have recognized fluctuations in values and are evidently distorted by seasonal occurrence of catastrophic losses. This finding is in line with climatic conditions in the Czech Republic, which is exposed to influence of non-life risks and primarily vulnerable to floods in summer months. Results should be further discussed with respect to irregular trends in catastrophes and floods and results in correlation analyses. Further analysis should verify impacts of risks on financial results of insurers. Nevertheless, influence of catastrophe risk on insurance and reinsurance markets is undeniable, which should be additionally discussed in relation to appropriate level of coverage of catastrophe losses.

\section{Conclusion}

Influence of catastrophe risk on insurance and reinsurance markets belongs to actual topics respecting adverse development in natural catastrophes. Insurance undertakings are exposed to impacts of non-life risk realization, especially floods, in conditions of the Czech insurance market. Deepening of influence is highlighted within unsystematic fluctuations of losses with impacts on the need to cover them by appropriate level of insurance protection with contribution of reinsurance.

Influence of catastrophe risk on insurance and reinsurance markets has been analysed through selected variables of catastrophe and flood losses, insurance premium and reinsurance premium. In comparison with stable levels of premiums, catastrophes and floods have been realized randomly throughout the monitored period. Loss events are realized mainly in the second quarters, which are caused by seasonal effects. Unchanging ratio of reinsurance premium on premium written has emphasized a necessity of appropriate coverage of extreme non-life risks with respect to unfavourable development in catastrophe losses. However, a lack of input data has not allowed a broader analysis based on statistically significant results of correlation among selected variables.

Main aim concerning the verification of the presumption of changes in reinsurance premium, which are not at comparable level of changes in catastrophe losses, respectively floods realized in conditions of the Czech market has been achieved by the analyses of annual and quarterly time series of selected variables. Relationship between premiums, especially reinsurance premium, and catastrophe losses has been found with regard to limited data. However, changes in losses are not fully covered by comparable level of changes in premiums. With respect to undeniable influence of catastrophe risk on insurance and reinsurance markets 
represented by insurance undertakings and reinsurers, coverage of extreme catastrophe losses should be improved by higher increase in premiums.

\section{References}

Arlt, J., Arltová, M., 2009. Ekonomické časové řady. Professional Publishing, Prague.

Banks, E., 2004. Alternative risk transfer. Integrated Risk Management through Insurance, Reinsurance and the Capital Markets. Wiley, England. DOI: 10.1002/9781118673270.

Berliner, B., 1985. Limits of Insurability of Risks. The Geneva Papers on Risk and Insurance - Issues and Practice 4, 313-329. DOI: 10.1057/gpp.1985.22.

Čamrová, L., Jílková, J., et al., 2004. Povodně jako prưřezový problém státní politiky. Institut pro ekonomickou a ekologickou politiku Fakulty národohospodářské, Vysoká škola ekonomická, Prague.

Česká asociace pojišt'oven (ČAP), 2017. Živelní škody. Prague, Czech Republic. Available from: <http://www.cap.cz/statisticke-udaje/zivly>. [March, 2017].

Česká národní banka (ČNB), 2017. Základní ukazatele o finančním trhu. Pojištovny celkem. ARAD systém časových řad. Prague, Czech Republic. Available from: <http://www.cnb.cz/cnb/STAT.ARADY_PKG.STROM_SESTAVY?p_strid=BC DA\&p_sestuid $=\& p \_l a n g=C S>$. [February, 2017].

Cipra, T., 2006. Pojistná matematika - teorie a praxe. Ekopress, Prague.

Cummins, D. J., 2007. Reinsurance for Natural and Man-Made Catastrophes in the United States: Current State of the Market and Regulatory Reforms. Risk Management and Insurance Review 2, 179-220. DOI: 10.1111/j.15406296.2007.00115.x.

Ducháčková, E., Daňhel, J., 2010. Teorie pojistných trhů. Professional Publishing, Prague.

Faure, M. G., Hartlief, T., 2003. Insurance and expanding systemic risks. Organisation for Economic Co-operation and Development, Paris. DOI: 10.1787/9789264102910-en.

Froot, K. A., 2001. The market for catastrophe risk: a clinical examination. Journal of Financial Economics 60, 529-571. DOI: 10.1016/s0304-405x(01)00052-6.

Garven, J. R., Tennant, J. L., 2003. The Demand for Reinsurance: Theory and Empirical Tests. Insurance and Risk Management 7, 217-237.

Pollner, J. D., 2012. Financial and Fiscal Instruments for Catastrophe Risk Management: Addressing Losses from Flood Hazards in Central Europe. World Bank Study, World Bank, Washington, DC. DOI: 10.1596/978-0-8213-9579-0. 
PricewaterhouseCoopers, 2015. Insurance 2020 \& beyond: Necessity is the mother of reinvention. Available from: <https://www.pwc.com/gx/en/insurance/ publications/assets/pwc-insurance-2020-and-beyond.pdf>. [July, 2015].

Swiss Re, 2015. Underinsurance of property risks: closing the gap. Sigma. Zurich, Switzerland. Available from: <http://media.swissre.com/documents/ sigma5_2015_en.pdf>. [May, 2015].

Swiss Re, 2016. Natural catastrophes and man-made disasters in 2015: Asia suffers substantial losses. Sigma. Zurich, Switzerland. Available from: <http://media.swissre.com/documents/sigma1_2016_en.pdf>. [January, 2016]. 
Appendix 1: Annual development in catastrophe loss, flood loss, reinsurance premium and premium written in 2008 - 2016 (mn CZK)

\begin{tabular}{lllll}
\hline Year & Catastrophe & Flood & Premium & Re. Premium \\
\hline 2008 & $2,936.0$ & 168.5 & $82,939.9$ & $23,425.1$ \\
2009 & $3,809.1$ & $1,508.9$ & $83,961.6$ & $22,714.0$ \\
2010 & $7,742.0$ & $3,743.2$ & $84,231.5$ & $25,920.3$ \\
2011 & $1,653.8$ & 336.8 & $83,083.5$ & $25,934.6$ \\
2012 & $2,243.4$ & 356.6 & $81,554.0$ & $25,127.5$ \\
2013 & $9,197.0$ & $7,269.8$ & $85,002.3$ & $25,999.2$ \\
2104 & $1,966.4$ & $1,013.0$ & $86,735.8$ & $26,208.7$ \\
2015 & $1,270.3$ & 68.2 & $91,034.2$ & $26,943.5$ \\
2016 & $1,910.9$ & 355.6 & $89,826.7$ & $25,365.4$ \\
\hline
\end{tabular}

Source: ČAP, 2017; ČNB, 2017.

Appendix 2: Additional information to analysis of annual time series in period 2008 - 2016 (units)

\begin{tabular}{lllll}
\hline & Catastrophe & Flood & D. Premium & D. Re.Premium \\
\hline $\begin{array}{l}\text { Number of } \\
\text { observations }\end{array}$ & 8 & 8 & 8 & 8 \\
$\begin{array}{l}\text { t-stat: } \\
\text { Catastrophe }\end{array}$ & - & & & \\
t-stat: Flood & 8.1378 & - & & \\
t-stat: & 0.7834 & 1.1862 & - & \\
$\begin{array}{l}\text { D.Premium } \\
\text { t-stat: D.RePremi }\end{array}$ & 2.1300 & 1.5950 & 1.0330 & - \\
Mean & $3,724.109$ & $1,831.526$ & 860.8548 & 242.5351 \\
Std. Dev. & $3,046.793$ & $2,498.587$ & $2,193.34$ & $1,454.128$ \\
Variance & $9,282,949$ & $6,242,937$ & $4,810,742$ & $2,114,489$ \\
\hline
\end{tabular}

Source: ČAP, 2017; ČNB, 2017; own calculations. 
Bártová, H..: Influence of Catastrophe Risk on Insurance and Reinsurance Markets.

Appendix 3: Recalculated quarterly development in catastrophe loss, flood loss, premium written and reinsurance premium in 4q2010 4q2016 (mn CZK)

\begin{tabular}{|c|c|c|c|c|}
\hline Quarter & Catastrophe & Flood & Premium & Re. Premium \\
\hline $4 q 2010$ & 555.7 & 342.1 & $20,009.0$ & $6,241.8$ \\
\hline 1q2011 & 325.3 & 92.6 & $22,495.2$ & $7,492.8$ \\
\hline $2 q 2011$ & 464.2 & 51.4 & $20,559.4$ & $6,105.2$ \\
\hline 3q2011 & 730.3 & 177.7 & $20,124.1$ & $5,943.7$ \\
\hline $4 q 2011$ & 133.9 & 15.1 & $19,284.8$ & $6,161.6$ \\
\hline 1q2012 & 186.5 & 41.9 & $21,948.5$ & $7,379.9$ \\
\hline $2 q 2012$ & 355.8 & 119.6 & $20,934.6$ & $6,153.1$ \\
\hline 3q2012 & $1,634.6$ & 184.0 & $19,814.1$ & $5,995.9$ \\
\hline $4 q 2012$ & 65.3 & 8.3 & $18,378.9$ & $5,536.6$ \\
\hline 1q2013 & 145.0 & 14.7 & $23,140.9$ & $7,540.3$ \\
\hline $2 q 2013$ & $7,304.3$ & $6,864.0$ & $21,703.1$ & $6,323.4$ \\
\hline $3 q 2013$ & $1,451.1$ & 360.9 & $20,166.8$ & $6,131.9$ \\
\hline $4 q 2013$ & 296.6 & 30.2 & $19,835.4$ & $5,996.6$ \\
\hline 1q2014 & 112.0 & 35.3 & $22,852.3$ & $7,350.9$ \\
\hline $2 q 2014$ & 962.7 & 607.0 & $21,947.7$ & $6,356.8$ \\
\hline $3 q 2014$ & 620.4 & 231.4 & $21,029.1$ & $6,301.2$ \\
\hline $4 q 2014$ & 401.1 & 223.7 & $20,734.5$ & $6,192.9$ \\
\hline 1q2015 & 317.9 & 6.0 & $23,906.8$ & $7,720.1$ \\
\hline $2 q 2015$ & 384.5 & 18.9 & $22,344.1$ & $6,371.4$ \\
\hline $3 q 2015$ & 497.1 & 37.5 & $22,727.3$ & $6,324.3$ \\
\hline $4 q 2015$ & 70.9 & 5.8 & $21,874.7$ & $6,521.9$ \\
\hline $1 q 2016$ & 60.7 & 4.7 & $24,118.5$ & $7,664.7$ \\
\hline 2q2016 & $1,193.4$ & 210.6 & $22,738.8$ & $6,177.8$ \\
\hline $3 q 2016$ & 591.3 & 120.6 & $21,854.3$ & $6,000.0$ \\
\hline $4 q 2016$ & 65.4 & 19.7 & $20,944.3$ & $5,519.2$ \\
\hline
\end{tabular}

Source: ČAP, 2017; ČNB, 2017; own calculations. 
Appendix 4: Quarterly development in catastrophe loss, flood loss, reinsurance premium and premium written in 4q2010 - 4q2016 (mn CZK)

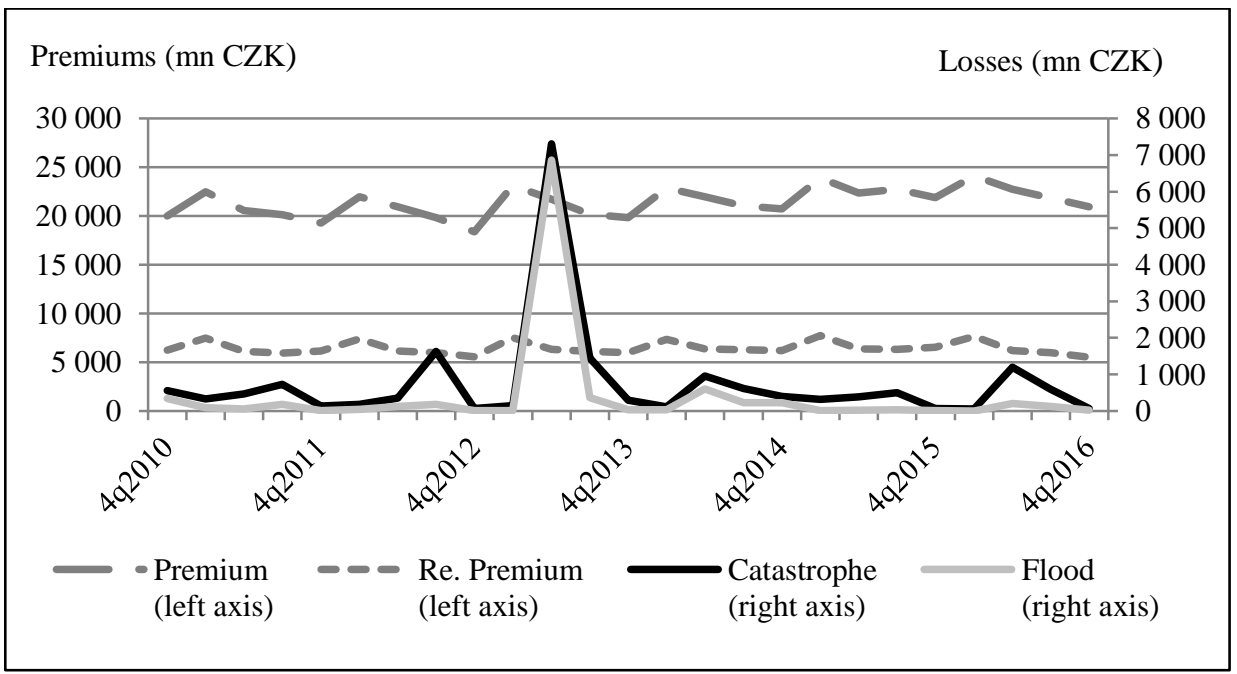

Source: С̌AP, 2017; ČNB, 2017; own calculations.

Appendix 5: Additional information to analysis of quarterly time series in period 4q2010 - 4q2016 (units)

\begin{tabular}{lllll}
\hline & Catastrophe & Flood & D. Premium & D. Re.Premium \\
\hline $\begin{array}{l}\text { Number of } \\
\text { observations } \\
\text { t-stat: }\end{array}$ & 24 & 24 & 24 & 24 \\
$\begin{array}{l}\text { Catastrophe } \\
\text { t-stat: Flood }\end{array}$ & - & & & \\
t-stat: & 11.7928 & - & & \\
$\begin{array}{l}\text { D.Premium } \\
\text { t-stat: D.RePremi }\end{array}$ & -0.1488 & -0.4134 & - & \\
Mean & 684.22 & 0.1243 & 4.5250 & - \\
Std. Dev. & 771.302 & 280.7726 & 32.86768 & -31.21336 \\
Variance & $594,906.7$ & 622.6323 & 623.5717 & 233.3675 \\
\hline
\end{tabular}

Source: ČAP, 2017; ČNB, 2017; own calculations. 
